\title{
Література:
}

1. Жулинський М. Г. Істина - в людських душах // Твори в $5 \mathrm{~m}$. К. : Дніпро. Т. 1 : Смерть Сократа. Суд над Сенекою. Гайдамаки. Жовтий цвіт кульбаби / Ю. М. Мушкетик. 1987. 608 с.

2. Любацька Г. І. I проросте в ділах людей... Роздум про творчість Ю. Мушкетика. Вітчизна. 1985. № 9. С. 164-169.

3. Мушкетик Ю. М. «Колись я був молодим і диким. Знов хотів би так, але не можу...»: інтерв'ю. Дніпро. 2010. № 10-11. С. 88-93.

4. Мушкетик Ю. М. Із гіркотою дивлюся на те, що нині відбувається. URL: https://vsiknygy.net.ua/interview/38541/ (дата звернення: 19.10.2014).

5. Мушкетик Ю. М. Чорний вершник: Поезії. К.: Укр. письменник, 1992. $126 \mathrm{c}$.

DOI https://doi.org/10.30525/978-9934-26-039-1-22

\section{ХУДОЖНЯ БАРОКОВА ІНТЕРПРЕТАЦІЯ СИСТЕМИ ЕКЗИСТЕНЦІЙНИХ КОНЦЕПТІВ У ПОЕЗІЇ ДАНИЛА БРАТКОВСЬКОГО ТА КЛИМЕНТІЯ ЗІНОВІЕВА}

\author{
Катюжинська А. О. \\ студентка IV курсу \\ Інституту філології \\ Київського національного університету імені Тараса Шевченка \\ м. Київ, Украӥна
}

У літературі епохи Бароко актуалізується філософська проблематика, зокрема система екзистенційних концептів. Письменники періоду Зрілого (Високого) Бароко, передусім Д. Братковський і К. Зіновіїв, яскраво втілили у своїх творах барокову художню парадигму 3 iï провідними характеристиками.

У творчості Д. Братковського та К. Зіновієва репрезентовано цілком барокову за своєї сутністю художньо-світоглядну концепцію. Передусім це ідеї швидкоплинності й минущості життя, консептизм, алегоричносимволічне переосмислення образної системи, метафори «світ - театр», «життя - мандрівка», «людина - мандрівник» тощо. Власне, система екзистенційних концептів реалізується через філософське відношення «людина - світ». У бароковій інтерпретації, репрезентованій у збірці поезій Д. Братковського «Світ, по частинах розглянутий», центральною $\epsilon$ проблема людської екзистенції. Так, у вірші «Світу відміни не втямити 88 
нині» провідними є ідеї швидкоплинності й мінливості світу: «Гей, як у світі напрочуд ведеться, Здоровий, хворий, той плаче, сміється, Кричить у небо чи радо голосить, Той їсть паштети, а той хліба просить...» $[2$, с. 59] За переконанням поета, амбівалентність і кардинальні протилежності $\epsilon$ основними характеристиками світу. Контраст проявляється у вічності світу й минущості людського життя, що актуалізує ідею про людину як піщинку у Всесвіті, де все постійно змінюється. Д. Братковський переосмислює світ через символ кола, що репрезентовано у вірші «Світ коло»: «Світ - коло, кажуть, колом обертає, Набуде доста, раптом утрачас. Усього збувшись, знову набуть може. Фортуни коло з рук твоїх, о Боже!» [2, с. 279] До ідей швидкоплинності й минущості світу апелює також К. Зіновіїв у вірші «Про змінності світові»: «В цьому світі всяка річ змінена буває, кожен світський чоловік й інок це признає. Не тривкі фортеці, ба - і всілякі мури, - знаю, все минається, як в повітрі хмури» [3, с. 91]. Окрім того, у вірші «Дим» провідним $є$ ідейне переконання про минущість світу, який переосмислюється через символ диму: «Незбагненна в світі річ: він куди зникає? За написаним хіба - так, «як дим щезає». Адже йде у вишину - там щоб розвітрятись, на землі не може він довго залишатись» [3, с. 87].

На думку I. Ісіченка, «Климентій є людиною бароко, а отже, його поетична мова побудована на парадоксах, концептах» [4, с. 14]. Творчість К. Зіновієва в контексті барокової стильової парадигми розглядає також П. Білоус: «Творчість Климентія Зиновіїва - нове явище в українській літературі, яке сприяло не лише розвитку бароко, а й демократизації літератур, що виявилося у зацікавленості простою людиною, співчутті їй, звернення до фольклорних джерел» [1, с. 257]. Прихильною до зазначеної є також думка В. Крекотня, який акцентує, що «книга віршів Климентія - видатне явище низового бароко» [6, с. 18]. Однак варто звернути увагу на те, що інтерпретаційна модель людини, яку представляє у своїй творчості К. Зіновіїв, відрізняється від запропонованої Д. Братковським. По суті, образ людини в К. Зіновієва характеризується двома складниками - антропоцентричним і теоцентричним, які взаємодоповнюються й відображають особливості барокового світогляду. Антропоцентризм як провідна риса літератури Ренесансу проявляється передусім через гуманістичне спрямування світоглядних переконань автора, на що вплинули життєві труднощі самого К. Зіновієва, який шанував просту людину й вимагав поваги до неї незалежно від матеріальних статків. Окрім того, належність поета до сану ченця-священика вплинула на стійку віру в Бога, що реалізується через теоцентризм як складник його світогляду: «Ідея теоцентризму яскраво виражена i в творчості Климентія Зіновієва... Климентій 
говорить про непізнанність природи Бога, про Його милосердя i всемогутність,про важливу роль церкви і Божого Слова (Біблії)..» [7, с. 3-4] 3 огляду на це, В. Колосова наголошує, що «переплетення цих двох факторів - клерикального і народного - становить найхарактернішу рису суперечливого світогляду Климентія...» [5, с. 12]

Центральною в авторських художньо-світоглядних інтерпретаціях $\epsilon$ бінарна опозиція екзистенційних концептів «життя - смерть». Власне, Д. Братковський подає філософські роздуми над проблемою людської екзистенції, апелюючи до барокового прийому контрасту. Тема смерті $\epsilon$ провідною в літературі епохи Бароко загалом і творах Д. Братковського та К. Зіновієва зокрема. Д. Братковський наголошує на тому, що людина не $\epsilon$ вічною й переосмислює життя як іскру (наприклад, вірш «Людський вік - іскра»): «Преглянься прецінь: як іскра ти, власне, Чи швидко, довго - посвітиш і згаснеш» [2, с. 329]. У світогляді барокової людини загострюється відчуття минущості світу, усвідомлення, що Всесвіт $€$ великим і необмеженим, характеризується вічністю, а натомість, на тлі цієї світової величі людина почуває свою мізерність і слабкість перед смертю, що поглиблює песимістичні мотиви: «Світ $є$ широкий, людей повно всюди, За сто літ жоден жить в світі не буде» (вірш «Світ як зника, глянь 3 прогностика») [2, с. 253]. Схожими є міркування К. Зіновієва, у системі екзистенційних концептів якого за принципом контрасту протиставляються життя і смерть, при цьому смерть осмислюється як те, перед чим людина $є$ безсилою, що репрезентовано у вірші «Смерть»: «Смерте, смерте, о чому ти є страхітлива? I не тільки наяву - в пам'яті жахлива! Багачів і бідаків ти не оминаєш і так само з душами всяких розлучаєш» [3, с. 100]. Картина світу, репрезентована в поетичній спадщині К. Зіновієва, характеризується універсальністю, на чому наголошує В. Шевчук: «Замислюючи написати універсальну книгу буття свого народу, Климентій укладає ії... за розділами і вибудовує у такий спосіб свою світоглядну схему» $[8$, с. 16]. Спільною ознакою в інтерпретації філософської проблеми «людина - світ» Д. Братковським і К. Зіновієвим є контрастність, суперечливість, складність i багатоаспектність. Відтак, П. Білоус, аналізуючи творчість К. Зіновієва, стверджує, що «намагання відобразити найрізноманітніші сторони життя, показати світ у всіх його аспектах і контрастах вказували на барокові тенденції» [1, с. 256].

Отже, на основі порівняльного аналізу системи екзистенційних концептів у поезії Д. Братковського та К. Зіновієва можемо зробити висновок про апелювання письменників до барокової художньо-світоглядної парадигми, що простежується на ідейному (швидкоплинність і минущість світу, «марнота марнот»), образному 
(«світ - театр», «світ - море», «людина - піщинка у Всесвіті» тощо) рівнях, а також на рівні поетики. Автори використовують художні прийоми, характерні для епохи Бароко, передусім символізм, алегоризм, прийоми гри, контрасту тощо, звертаються до філософських роздумів, переосмислюючи проблему людської екзистенції, зокрема тему смерті. Основна відмінність полягає в тому, що інтерпретаційна модель образу людини, репрезентована в поезії К. Зіновієва, має подвійне спрямування й характеризується двома складниками - антропоцентризмом i теоцентризмом. Екзистенційні концепти Д. Братковського та К. Зіновієва відображають барокову художню інтерпретацію й свідчать про належність творчості письменників до літератури епохи Зрілого (Високого) Бароко.

\section{Література:}

1. Білоус П.В. Історія української літератури XI-XVIII ст. Київ: Академія, 2009. 424 с.

2. Братковський Д.Б. Світ, по частинах розглянутий / за ред. В.О. Шевчука. Луцьк: Видавництво обласної друкарні, 2004. 463 с.

3. Зіновіїв К. Вірші. Слово многоиінне: хрестоматія укр. літ., створеної різними мовами в епоху Ренесансу (друга половина $X V-X V I \mathrm{~cm}$.) та в епоху Бароко (кінець XVI-XVIII cm.) / за ред. В.О. Шевчука, В.В. Яременка. Київ: Аконіт, 2006. Т. 3. С. 86-318.

4. Ісіченко I. Концепт свободи в поетичному коді Климентія Зіновієва. Вісник Харківського наиіонального університету імені В.Н. Каразіна. Серія «Філологія». 2018. Вип. 78. С. 7-15.

5. Колосова В.П., Чепіга І.П. Визначна пам'ятка українського письменства. Зіновіїв К. Вірші. Приповісті посполиті / за ред. І.П. Чепіги. Київ: Наукова думка, 1971. С. 5-27.

6. Крекотень B.I. Українська література XVII ст. Украӥнська література XVII ст.: Синкретична писемність. Поезія. Драматургія. Белетристика. Київ: Наукова думка, 1987. С. 5-24.

7. Меркулов М.Р. Творчість Климентія Зіновієва в контексті української літератури доби Бароко: дисертація на здобуття наукового ступеня кандидата філологічних наук (доктора філософії): 10.01.01. Київ, 2020. $202 \mathrm{c}$.

8. Шевчук В.О. Климентій Зиновіїв і його книга буття українського народу. Зіновіїв K. Золоте чересло. Книга народних ремесел, звичаїв та побуту в Україні, писана Климентісм Зіновісвим, поетом кіния XVII - початку XVIII cm. / за ред. В.О. Шевчука. Київ: Мистецтво, 2009. C. 5-28. 